\title{
PERASAAN INSECURE PADA MASA COVID-19 MENGAKIBATKAN MARAKNYA ORANG MENJUAL PRODUK KECANTIKAN
}

\author{
Riezka Annisa Rahmah \\ Mahasiswa S1 Psikologi, Fakultas Kedokteran, \\ Universitas Lambung Mangkurat, Banjarbaru, Indonesia.
}

Email:2010914220011@mhs.ulm.ac.id

\begin{abstract}
Abstrak
Dalam hal ini, saya ingin membahas tentang perasaan insecure yang kebanyakan mengarah pada perbandingan kecantikan yang muncul pada masa Covid-19. Perasaan insecure banyak dialami para wanita-wanita muda, dan juga insecure ini kurang lebih saja dengan perasaan tidak percaya diri. Oleh karena itu, para wanita berlomba-lomba untuk merawat wajahnya hingga banyak sekali orang menjual produk-produk kecantikan karena hal tersebut. Insecure berawal dari tren kecantikan yang di sebut "glowing" dan juga "glow up", karena kebanyakan para influencer, seleb, dan lainnya memperlihatkan wajah yang mulus tanpa jerawat, pori-pori dan tampak bercahaya. Kemudian para wanita mulai iri dengan wajah yang terawat tersebut hingga mulai bertanya-tanya tentang produk apa yang telah digunakan, sampai akhirnya semakin banyak wanita yang memperlihatkan kecantikan wajahnya dan sebagian wanita yang memiliki permasalahan wajah yang sulit sembuh pun merasa insecure atau tidak percaya diri.
\end{abstract}

Kata Kunci : Insecure, Produk Kecantikan, Covid-19.

\section{Abstract}

In this case, I want to talk about feelings of insecurity which mostly lead to comparisons of beauty that emerged during the Covid-19 period. Feelings of insecure are experienced by many young women, and also this insecure is more or less with a feeling of insecurity. Therefore, women are competing to take care of their faces so many people sell beauty products because of this. Insecure originated from a beauty trend called "glowing" and also "glow up", because most influencers, celebrities, and others show smooth faces without acne, pores and look radiant. Then the women started to be jealous of the well-groomed faces and began to wonder about what products had been used, until finally more and more women showed their beautiful faces and some women who had facial problems that were difficult to heal also felt insecure or not confident.

Keywords: Insecure, Beauty Products, Covid-19.

\section{PENDAHULUAN}

Insecure merupakan perasaan tidak aman [1] yang dimana seorang individu merasa tidak percaya diri, cemas dan lainnya akan suatu hal. Glowing artinya kulit sehat bercahaya, dan glow up artinya perubahan seseorang menjadi lebih baik. Pada saat ini orang-orang sering sekali menyebutkan kata insecure ketika melihat orang yang lebih cantik atau yang lebih tampan. Setiap orang memiliki perasaan insecure masingmasing pada hal-hal tertentu. Seperti saya 
sendiri, saya juga merasa insecure melihat teman-teman saya yang cantik-cantik dan populer. Saya merasa tidak nyaman dan malu jika jalan-jalan bersama mereka, dan saya juga berusaha membeli berbagai produk kecantikan untuk bisa mengimbangi mereka, namun malah wajah saya tambah jerawatan dan membuat saya semakin tidak percaya diri dan malu untuk bertemu dengan orangorang. Perasaan insecure ini tergantung situasi memang bisa menyebabkan stress bahkan depresi.

Di Indonesia sekarang ini, karena masa Covid-19 orang-orang melakukan berbagai hal dan tren di internet, salah satunya yaitu tren kecantikan seperti wajah glowing hingga insecure. Awal tren kecantikan ini karena ada beberapa seleb di internet yang menyebutkan bahwa pada masa pandemi ini lebih baik merawat dan mempercantik diri, biar orang-orang terkejut akan perubahan kita di saat pandemi telah berakhir. Dan ada juga yang bilang kalau uang kita lebih baik dipakai untuk membeli produk kecantikan daripada baju, supaya kalau berfoto kita tidak perlu pakai filter lagi.

Hal-hal tersebut membuat motivasi sebagian orang untuk membeli produk-produk kecantikan dan sebagian yang sudah berhasil memperlihatkan kecantikan atas keberhasilan mereka merawat diri yang biasa orang sebut sebagai glow up. Orang-orang yang melihatnya pun mengatakan bahwa dirinya insecure, dan saat awal-awal tren kata insecure banyak yang bertanya-tanya maksud dari kata tersebut. Dan orangorang juga menganggap kata insecure sebagai kata untuk rasa tidak percaya diri akan kecantikannya, padahal arti kata insecure sangat luas.

Di Indonesia menilai sebuah kecantikan salah satunya dari warna kulit yaitu kulit yang putih. Saya sebagai salah satu pengamat dunia internet memperhatikan orang-orang yang mengatakan kalau dirinya insecure, dan setelah saya cek fotonya, ternyata orangnya cantik, putih dan jauh dari apa yang dia sebutkan. Jadi saya sempat sedikit bingung dengan orang-orang yang sudah cantik tapi mengatakan kalau dia insecure akan kecantikan orang lain. Tapi ternyata hal tersebut karena kurangnya rasa bersyukur. Saya sendiri juga sudah mencoba untuk bersyukur dan menganggap bahwa saya merawat diri merupakan merawat fisik yang diberikan oleh Allah SWT. Tapi setiap melihat teman-teman dan tekanan dilingkungan juga mempengaruhi saya dalam mempertahankan rasa bersyukur ini.

Percaya diri membuat seseorang bisa bersyukur atas apa yang dimiliki dan dapat menjalani kehidupan untuk bisa memperhitungkan pilihan atas keputusan diri [2]. Tapi karena kita hidup dalam kehidupan sosial, lingkungan juga mempengaruhi individu dalam menilai sesuatu. Kebutuhan seorang teman membuat seorang individu terpengaruh untuk menyesuaikan diri dalam kepentingan dan keinginan lingkungan kita [3]. Apalagi saat masa-masa muda atau remaja yang dimana sudah mulai mengenali lingkungan dan orang-orang disekitarnya [4], saat itulah individu merasakan persaingan dunia.

Oleh karena itu, misal ruang lingkup pertemanan kita menjunjung tinggi permasalahan kecantikan, dan menilai bahwa cantik itu harus putih dan lainnya. Dari hal tersebut bisa saja berakhir menjadi suatu pembullyan walau secara perkataan yang mengenai mental dan perasaan tanpa empati atau menghargai perasaan seseorang [5] karena mereka merasa dirinya sudah masuk kriteria cantik. Tapi respon setiap individu dalam tuntutan ini berbeda-beda [6]. Dan kemudian kita bisa menjadi merasa malu karena kita tidak termasuk kriteria tersebut, kita pun memaksa diri ini untuk melakukan apapun untuk bisa mencapai kriteria tersebut, apalagi di 
jaman sekarang ada sebutan "Keadilan sosial bagi yang good looking", yang artinya segala hal yang tampak cantik diluar walau melakukan suatu kesalahan besar orang-orang akan menerimanya. Dan akhirnya kebanyakan anak muda berlomba-lomba merawat diri agar bisa di akui di lingkungan sosialnya dan di lingkungan luas.

Para pembisnis seperti penjual online memanfaatkan tren dimana tingkat penjualan produk kecantikan semakin meningkat, apalagi kita di masa pandemi Covid-19 ini sangat kesulitan mencari uang tambahan. Tapi kita tetap harus berhati-hati dengan produk-produk yang kandungannya berbahaya untuk kedepannya, karena ada beberapa oknumoknum tertentu yang menggunakan bahan seperti merkuri atau hidroquinon agar pengguna dapat cepat merasakan perubahan di wajahnya, seperti cepat putih, mulus dan glowing.

Produk-produk kecantikan dari korea adalah salah satu produk yang populer, apalagi tahu bahwa korea terkenal akan kecantikan para artisartisnya. Ditambah dari para seleb dan influencer yang mempromosikan berbagai produk kecantikan yang mereka gunakan. Orang-orang yang melihat sebagian percaya karena terkadang ada bukti perubahan mereka yang dulu hingga sekarang.

Produk-produk kecantikan memiliki tingkat harga yang berbedabeda tergantung kualitas dan khasiatnya. Tapi kebanyakan hargaharganya lumayan mahal walau isinya hanya sedikit atau beberapa mili saja. Sebenarnya produk kecantikan hanya keperluan tambahan sebagai merawat diri, dan hanya orang-orang menengah ke atas yang bisa membelinya. Dan jika mengikuti nafsu untuk mencoba-coba produk yang di promosikan seorang seleb di sosial media, hal itu hanya akan merugikan diri sendiri apabila produknya tidak cocok untuk kulit kita, dan jika kita mencoba banyak produk dalam waktu berdekatan dan mencoba menggabungkan berbagai merk produk, salah-salah wajah atau kulit kita akan rusak.

Belanja merupakan suatu kegiatan membeli barang untuk memenuhi kebutuhan, apalagi sekarang sudah banyak orang yang menjual berbagai keperluan seperti toko online dalam aplikasi. Orang-orang bebas mengakses dan mudah untuk mencari barang yang diinginkan tanpa harus keluar rumah dan keliling-keliling pasar.[7]

Membeli produk kecantikan untuk mengikuti tren juga merupakan suatu sikap konsumtif karena ingin menjaga penampilan diri, gengsi, membeli berdasarkan harga tanpa tau manfaatnya, kemasannya menarik, dan karena model yang mengiklankan produknya terlihat bagus padanya padahal belum tentu bagus pada diri kita, dan membeli produk yang mahal untuk meningkatkan kepercayaan diri [8]. Dan jika mereka berhasil dalam merawat diri juga akan menghasilkan kepuasan dalam dirinya.

\section{METODE}

Metode yang digunakan dalam pembahasan ini adalah dengan metode kajian literatur, yang dimana saya mengambil dari beberapa referensi seperti jurnal. Cakupan dalam yang saya bahas dari lingkungan sekitar, hingga lingkungan luas yaitu di Indonesia.

Saya mengambil beberapa artikel dan buku dari dosen-dosen di Program Studi Psikologi, Fakultas Kedokteran, Universitas Lambung Mangkurat, yaitu beberapa artikel dari Ibu Rika Vira Zwagery M.Psi dan penulis lain yang berjudul Hubungan Pola Asuh Orang Tua dengan Kepercayaan Diri Remaja di SMK Borneo Lestari Banjarbaru. Saya mengutip pada bagian kepercayaan diri 
yang ada hubungannya dengan tulisan saya, artikel Perbedaan Kualitas Persahabatan Ditinjau Dari Gaya Kelekatan Pada Mahasiswa Psikologi Fakultas Kedokteran Ulm, yang saya kutip pada bagian dimana anak muda yang mulai mengenali lingkungan

Beberapa artikel dari Ibu Marina Dwi Mayangsari, M.Psi., Psikolog dan penulis lainnya, yaitu, Hubungan Kepercayaan Diri dengan Konformitas Pada Remaja. Yang dimana saya mengutip pada bagian kepercayaan diri, artikel Pengaruh Perilaku Modeling pada Tayangan Drama Korea terhadap Citra Diri Remaja Penggemar Drama Korea. Yang dimana saya mengutip bagian zaman globalisasi yang mengembangkan teknologi yang berkaitan dengan zaman sekarang.

Artikel dari Ibu Dwi Nur Rachmah, S.Psi., M.A, yaitu, Empati pada pelaku bullying. Saya mengutip pada bagian dimana orang-orang masih banyak yang kurang berempati dan perilaku orang kebanyakan yang tidak peduli dengan perasaan orang lain.

Artikel dari Ibu Meydisa Utami Tanau M.Psi., Psikolog, dan penulis lainnya, yaitu, Hubungan Efikasi Diri Dengan Stress Pada Mahasiswa Yang Berada Dalam Fase Quarter Life Crisis. Yang dimana saya kutip pada bagian bahwa respon setiap individu itu berbeda.

Ibu Emma Yuniarrahmah S.Psi, M.A, dan penulis lainnya, yaitu, Pengaruh jejaring sosial terhadap kebutuhan afiliasi remaja di program Studi Psikologi Fakultas Kedokteran Universitas Lambung Mangkurat. Yang dimana saya kutip pada bagian teknologi komunikasi dan informasi.

Bapak Prof. Ersis Warmansyah Abbas, dan Ibu Neka Erlyani S.Psi, M.Psi, yaitu Menulis di Kala Badai Covid-19. Yang dimana saya kutip tentang tulis menulis yang berhubungan dengan penulisan ini. Dan juga dari Prof Ersis sendiri tentang Menulis di Era Covid-19: Memanage Trauma Psikologis Menghindari Psikosomatis. Menulis di Era Covid-1.

Artikel dari Ibu Dr. Silvia Kristanti Tri Febriana, M.Psi., Psikolog, yaitu, ). Hubungan Antara Gaya Hidup Konsumtif dengan Keputusan Pembelian Perhiasan Emas Pada Pelanggan Toko Emas di Kawasan BanjarmasinBanjarbaru-Martapura. Yang dimana saya kutip pada bagian pengertian belanja, yang berhubungan dengan tulisan saya yaitu membeli produk kecantikan yang kebanyakan melalui toko online.

Artikel dari Ibu Rahmi Fauzia, S.Psi, M.Psi, dan penulis lainnya, yaitu Hubungan Antara Kepuasan Citra Tubuh Dengan Kecenderungan Body Dysmorphic Disorder Pada Wanita Dewasa Awal Di Kota Banjarbaru. Yang saya kutip pada bagian anggapan pentingnya penampilan seseorang

Artikel dari Bapak Muhammad Syarif Hidayatullah, S.Psi, M.Psi, Psikolog dan penulis lainnya yaitu Hubungan Kontrol Diri Dengan Perilaku Konsumtif Konsumen Online Shop Melalui Sosial Media Pada Mahasiswa Program Studi Psikologi Universitas Lambung Mangkurat. Yang saya kutip pada bagian perilaku konsumtif, karena produk kecantikan hanya kebutuhan tambahan untuk merawat diri dan harganya pun lumayan tinggi. Dan saya juga mengambil salah satu artikel yang ada di Google Scholar yang berhubungan dengan apa yang saya bahas dalam tulisan saya ini. Yaitu, dari Mu'awwanah, U. (2017) tentang Perilaku Insecure Pada Anak Usia Dini. Yang saya ambil sebagai dasar pengertian dari kata insecure.

Tulisan yaitu dimana kita mendapat suatu informasi, diolah dan disimpan di dalam otak terlebih dahulu sebagai memori, kemudian 
merealisasikannya dalam bentuk tulisan dengan menulis[9].

Kita mendapatkan suatu informasi melalui pancaindra, dari apa yang dirasakan, dilihat dan didengar yang kemudian kita simpan dalam memori [10]. Seperti hal yang saya bahas dalam tulisan ini juga berasal dari opini, dan informasi yang sering saya dengar, saya lihat dan saya rasakan sendiri, yang akhirnya saya jadikan dalam bentuk tulisan.

\section{HASIL DAN PEMBAHASAN}

Pada zaman globalisasi dimana teknologi sudah berkembang, kita sangat mudah mengakses segala hal informasi di internet [11]. Berbagai sarana komunikasi dan informasi lewat berbagai aplikasi yang sudah banyak berkembang dalam telepon genggam atau handphone dan kecepatan internet juga semakin maju[12]. Apalagi saat masa pandemi Covid-19 ini kita harus banyak berdiam diri dirumah dan kebanyakan menggunakan handphone atau laptop untuk melakukan segala kegiatan secara daring atau online. Dari sekolah atau kuliah online, seminar atau webinar online, lomba-lomba yang dilaksanakan secara online, hingga jual beli online.

Kebanyakan anak muda suka sekali membuka aplikasi sosial media seperti Instagram, Whatsapp, dan akhirnya mereka terpengaruh dengan halhal yang sedang tren, misalnya tentang kecantikan. Seperti di Indonesia sendiri memang sudah lama menilai kecantikan dari warna kulit yaitu kulit putih dan mulus. Para seleb dan influencer memperlihatkan kecantikannya dalam sosial media mereka, hingga ada yang menggunakan istilah "insecure" untuk dirinya yang sangat jauh dari cantiknya para seleb tersebut hingga kata tersebut menjadi viral sampai orang yang sudah cantik sekalipun menggunakan kata tersebut saat melihat orang yang cantik juga. Kemudian banyak anak muda yang bertanya-tanya tentang produk apa yang digunakan agar memiliki kulit yang terawat, glowing, putih dan mulus. Saat itulah banyak sekali yang mempromosikan atau memamerkan produk kecantikan yang mereka gunakan.

Orang-orang yang tergiur karena ingin cantik berlomba-lomba membeli produk incarannya di toko-toko online. Sampai banyak sekali produk kecantikan yang sold out. Para pembisnis yang melihat hal tersebut juga ikut berlombalomba untuk menjual berbagai produk kecantikan.

Demi bisa berubah menjadi lebih baik atau glow up, mereka rela menghabiskan uang yang banyak untuk merawat diri. Ditambah dari lingkungan sekitar hingga dunia yang kebanyakan tidak adil atau mendiskriminasi orang yang tidak cantik atau tampan. Hingga ada sebutan "keadilan sosial bagi yang goodlooking". Oleh karena itu banyak orang yang merasa insecure dan bisa saja memiliki sifat konsumtif karena memaksa diri dan tidak sabra untuk mendapatkan hasil yang memuaskan.

Para wanita-wanita muda yang sudah memahami tentang pentingnya penampilan menganggap penampilan sebagai bagian dari harga dirinya, karena banyak yang memberikan penilaian pada penampilan yang akhirnya berpengaruh pada harga diri[13].

Untuk bisa mengurangi rasa insecure dalam diri kita memang sangat sulit karena ini berkaitan dengan perasaan. Dan perasaan setiap orang berbeda-beda tergantung bagaimana individu menangkap suatu hal. Bisa saja kita mencoba untuk lebih mensyukuri apa yang ada yang diberikan oleh Tuhan, lebih melihat kelebihan-kelebihan yang ada pada diri kita walaupun hanya hal kecil saja, menutup mata jika kita melihat hal-hal yang akan menambah rasa insecure kita, menutup telinga dari perkataan-perkataan orang sekitar yang 
menghina fisik atau warna kulit kita, belajar untuk tidak peduli perkataan orang lain dan menyibukkan diri pada hal-hal yang kita sukai, tapi kita tetap harus merawat diri kita sebagai bentuk menghargai ciptaan-Nya.

\section{SIMPULAN}

Jadi, kesimpulan yang bisa diambil dalam bahasan ini adalah:

1. Kata-kata yang sedang tren seperti glow up, glowing dan sebagainya yang dipopulerkan orang-orang dalam dunia kecantikan hingga menghasilkan kata insecure bagi orang-orang yang tidak percaya diri melihat kecantikan orang lain walau di dunia maya.

2. Perasaan insecure dipengaruhi oleh penilaian-penilaian orang sekitar dan lingkungan luas.

3. Perasaan insecure karena sering membandingkan diri dengan orangorang yang lebih baik dari kita, dan membuat rasa tidak pantas dan tidak percaya diri.

4. Pandangan orang Indonesia masih banyak yang menilai kecantikan dari warna kulit.

5. Orang-orang berlomba-lomba untuk merawat diri agar saat pandemi selesai atau saat pertemuan oflline mereka percaya diri, ingiin dipuji atas keberhasilannya untuk jadi cantik atau tampan.

6. Para anak muda yang sudah paham tentang pentingnya penampilan memaksa diri untuk melakukan segala hal walau itu bersifat konsumtif demi kepuasan diri.

7. Peningkatan penjualan produk kecantikan karena orang-orang yang berlomba-lomba ingin merawat diri pada masa Covid-19 dan juga dipengaruhi oleh promosi atau iklan dari seleb dan model dan influencer.

8. Pada tren kecantikan ini bisa kita manfaatkan untuk menambah penghasilan di masa Covid-19 dari menjual produk kecantikan dengan berjualan online

Saran yang bisa saya berikan kepada kalian yang merasa insecure pada dirinya, banyak-banyaklah bersyukur walau sering sekali kita lupa untuk bersyukur, saat ingin menggunakan produk kecantikan jangan lupa niatkan sebagai bentuk anda merawat dan menghargai fisik ciptaan dari Tuhan, lakukan segala hal atau hobi yang kalian sukai untuk membantu melupakan perkataanperkataan orang-orang mengenai fisik anda.

\section{DAFTAR PUSTAKA}

[1] Mu'awwanah, U. (2017). PERILAKU INSECURE PADA ANAK USIA DINI. aṣ-șibyān: Jurnal Pendidikan Anak Usia Dini, 2(01), 47-58.

[2] Saputri,L. K., Lestari, D. R., \& Zwagery, R. V. (200). Hubungan Pola Asuh Orang Tua dengan Kepercayaan Diri Remaja di SMK Borneo Lestari Banjarbaru. Dunia Keperawatan: Jurnal Keperawatan dan Kesehatan, 8(1), 3442.

[3] Mayara, B. H., Yuniarrahmah, E., \& Mayangsari, M. D. (2017). Hubungan Kepercayaan Diri dengan Konformitas Pada Remaja. Jurnal Ecopsy, 3(2).

[4] Putri, L. A., Anward, H. H., \& Zwagery, R. V. (2020). PERBEDAAN KUALITAS PERSAHABATAN DITINJAU DARI GAYA KELEKATAN PADA MAHASISWA PSIKOLOGI FAKULTAS KEDOKTERAN ULM. Kognisia prodi Psikologi FK ULM, 1(1), 23-28.

[5] Rachmah, D. N. (2016). Empati pada pelaku bullying. Jurnal Ecopsy, 1(2).

[6] Afnan, A., Fauzia, R., \& Tanau, M. U. (2020). HUBUNGAN EFIKASI DIRI DENGAN STRESS PADA MAHASISWA YANG BERADA DALAM FASE QUARTER LIFE 
CRISIS. Jurnal Kognisia: Jurnal Mahasiswa Psikologi Online, 3(1), 2329.

[7] Oktari, A. D., Dewi, R. S., \& Febriana, S. K. T. (2016). Hubungan Antara Gaya Hidup Konsumtif dengan Keputusan Pembelian Perhiasan Emas Pada Pelanggan Toko Emas di Kawasan Banjarmasin-Banjarbaru-

Martapura. Jurnal Ecopsy, 1(4).

[8] Renaldy, M., Dewi, R. S., \& Hidayatullah, M. S. (2020). HUBUNGAN KONTROL DIRI DENGAN PERILAKU KONSUMTIF KONSUMEN ONLINE SHOP MELALUI SOSIAL MEDIA PADA MAHASISWA PROGRAM STUDI PSIKOLOGI UNIVERSITAS LAMBUNG MANGKURAT. Kognisia prodi Psikologi FK ULM, 1(1), 94-97.

[9] Abbas, E. W., \& Erlyani, N. (2020). Menulis di Kala Badai Covid-19.

[10] WARMANSYAH ABBAS, E. R. S. I. S. (2020). Menulis di Era Covid-19: Memanage Trauma Psikologis Menghindari Psikosomatis. Menulis di Era Covid-19: Memanage Trauma Psikologis Menghindari Psikosomatis.

[11] Apsari, L., Mayangsari, M. D., \& Erlyani, N. (2017). Pengaruh Perilaku Modeling pada Tayangan Drama Korea terhadap Citra Diri Remaja Penggemar Drama Korea. Jurnal Ecopsy, 3(3).

[12] Aridarmaputri, G. S., Akbar, S. N., \& Yuniarrahmah, E. (2016). Pengaruh jejaring sosial terhadap kebutuhan afiliasi remaja di program Studi Psikologi Fakultas Kedokteran Universitas Lambung Mangkurat. Jurnal Ecopsy, 3(1).

[13] Santoso, M. V., Fauzia, R., \& Rusli, R. (2020). HUBUNGAN ANTARA KEPUASAN CITRA TUBUH DENGAN KECENDERUNGAN BODY DYSMORPHIC DISORDER PADA WANITA DEWASA AWAL DI KOTA
BANJARBARU. Kognisia

prodi 